\title{
O PRACACH NAD NOWĄ MAPA PRZEMARZANIA GRUNTU W POLSCE
}

\author{
Jerzy A. Żurański ${ }^{1 凶}$, Tomasz Godlewski', Sławomir Wereski² \\ ${ }^{1}$ Instytut Techniki Budowlanej, Warszawa \\ ${ }^{2}$ Instytut Meteorologii i Gospodarki Wodnej - Państwowy Instytut Badawczy, Warszawa
}

\begin{abstract}
STRESZCZENIE
W artykule przedstawiono dotychczasowy stan normalizacji głębokości przemarzania gruntu i ostatnie propozycje jego zmiany. Dwie z nich wykorzystują podejście polegające na zastosowaniu tzw. wskaźnika mrozowego, czyli liczby stopniodni ujemnej temperatury powietrza. Przedstawiono też nowe podejście polegające na wykorzystaniu danych pomiarowych temperatury gruntu, zgromadzonych przez stacje meteorologiczne Instytutu Meteorologii i Gospodarki Wodnej - Państwowego Instytutu Badawczego. Stosując rozkład prawdopodobieństwa Gumbela, wyznaczono głębokości położenia izotermy zerowej o okresie powrotu 50 lat. Uwzględniając warunki gruntowe na stacjach, sprowadzono otrzymane wyniki do warunków gruntu referencyjnego i zaproponowano nową mapę przemarzania gruntu.
\end{abstract}

Słowa kluczowe: temperatura gruntu, rozkład prawdopodobieństwa, okres powrotu, głębokość izotermy zerowej

\section{WSTĘP}

\section{Czynniki wpływające na przemarzanie gruntu}

Przemarzanie gruntu jest wielowymiarowym, niestacjonarnym procesem losowym. Zależy ono, z jednej strony, od losowo zmiennych zjawisk zewnętrznych, klimatycznych oraz od częściowo stałych, a częściowo także losowo zmiennych pod wpływem warunków zewnętrznych właściwości gruntu. Losowo zmiennymi warunkami zewnętrznymi są przede wszystkim: temperatura powietrza i opady śniegu, tworzące pokrywę śnieżną na gruncie, prędkość wiatru wpływająca na tę pokrywę oraz opady deszczu, zwłaszcza przed początkiem zamarzania gruntu, gdyż od nich zależy jego wilgotność. Także temperatura powietrza przed porą chłodną ma wpływ na przemarzanie gruntu, bowiem kształtuje jego temperaturę początkową. Przemiana pokrywy śnieżnej na gruncie, jej metamorfoza pod wpływem czynników zewnętrznych, temperatury powietrza, opadów i wiatru ma również charakter losowy. Wpływa ona na grubość pokrywy śnieżnej i przewodność cieplną śniegu, zależną od jego zmieniającej się gęstości.

Głębokość, do której sięga przemarzanie gruntu, jest najczęściej utożsamiana z położeniem izotermy zerowej w gruncie. Oprócz czynników zewnętrznych przemarzanie zależy oczywiście od rodzaju gruntu, jego konsystencji, składu i zawartości wody. W związku z tym nie zawsze głębokość przemarzania jest taka sama jak położenie izotermy zerowej. Ponieważ stacje meteorologiczne mierzą temperaturę gruntu i na tej podstawie wyznaczają położenie izotermy zerowej, będzie ona tu uznawana za głębokość przemarzania.

$\otimes_{\text {j.zuranski@itb.pl }}$ 
Od 1955 roku głębokość przemarzania jest podawana w polskich normach, a ostatnią zmianę wprowadzono w 1974 roku. Dzięki pomiarom wykonywanym przez stacje meteorologiczne Instytutu Meteorologii i Gospodarki Wodnej - Państwowego Instytutu Badawczego został zgromadzony zasób danych o temperaturze gruntu, umożliwiający ich analizę probabilistyczną i podanie propozycji zmian na normowej mapie przemarzania gruntu.

\section{Dotychczasowe mapy przemarzania gruntu w Polsce}

Pierwsza norma dotycząca gruntów budowlanych, pod nazwą Norma tymczasowa ukazała się w 1945 roku. Napisano w niej, że ,ze względu na przemarzanie - fundamenty zewnętrzne ścian budynków zwykłych powinny być zagłębione co najmniej: w województwach zachodnich 1,0-1,2 m, w środkowych 1,2-1,6 m, we wschodnich 1,5-2,0 m w zależności od gruntu i ważności budynku".

Można sądzić, że podane wartości zagłębienia w gruncie to nie tylko głębokość położenia izotermy zerowej, lecz także pewien zapas bezpieczeństwa, konieczność zagłębienia poniżej tej izotermy.

W normach z 1955 i 1959 roku jest ta sama mapa. Podano tam trzy strefy głębokości przemarzania: 0,8, 1,0 i 1,2 m. Mapa w normie z 1974 roku trochę się od niej różni. Znalazła się tu dodatkowo strefa 1,4 m, obejmująca północno-wschodni skrawek Polski, na wschód od Kętrzyna, przez Ełk, do granicy państwowej między Sokółką a Dąbrową Białostocką. W normie z 1981 roku powtórzono tę samą mapę, lecz ze zmniejszoną liczbą naniesionych miejscowości (rys. 1). Norma ta jest aktualna do dnia dzisiejszego.

Autorzy map normowych z lat 1955, 1959 i 1974 nie pozostawili informacji, jak te mapy były opracowywane. Na podstawie obszernej publikacji z 1962 roku (Wiłun, Piastowski i Kowalewski, 1962), a także sytuacji politycznej na początku lat 50. XX wieku, można wnioskować, że korzystali z radzieckich wytycznych (NiTU $-127-50,1950)$.

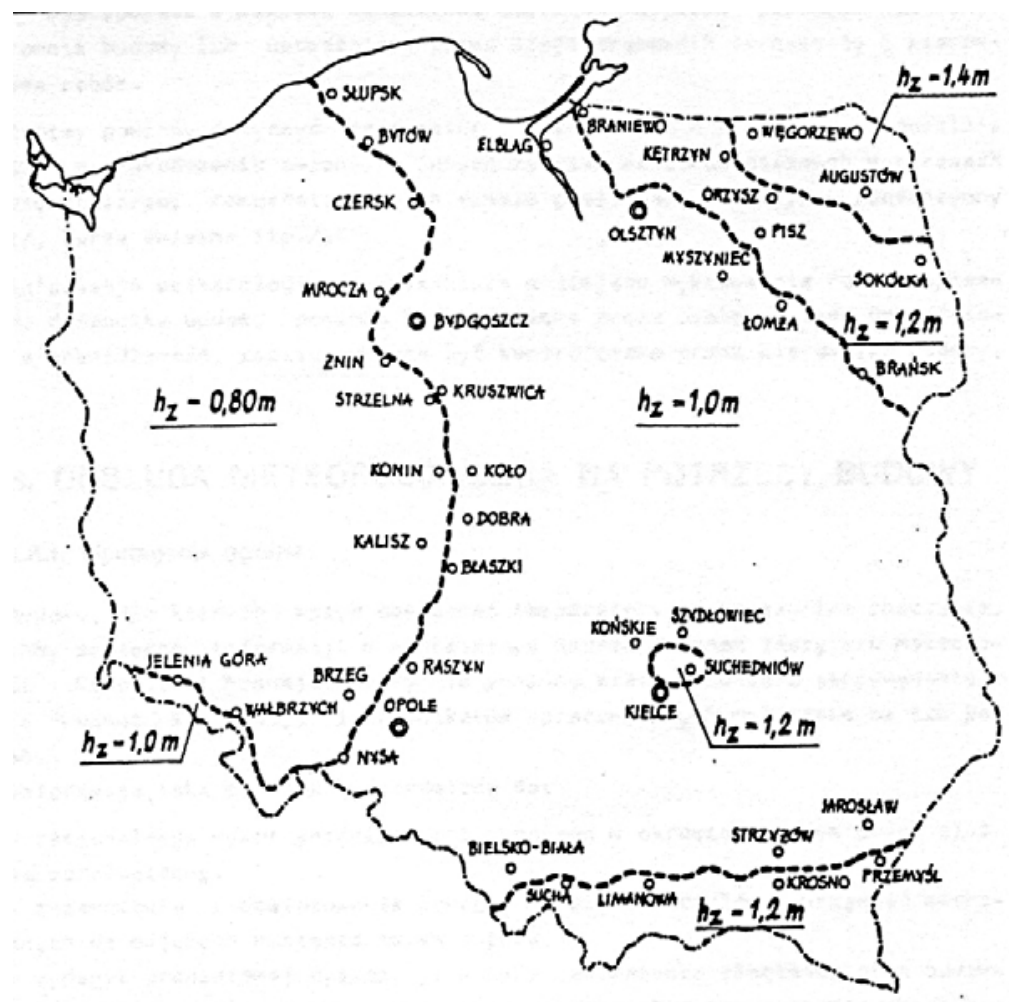

Rys. 1. Mapa przemarzania gruntu w Polsce z normy z 1981 roku (PN-81/B-03020)

Fig. 1. Map of soil freezing in Poland from the standard of 1981 (PN-81/B-03020) 
Według wytycznych z 1955 roku (a zapewne także według wydania wcześniejszego) głębokość przemarzania oblicza się ze wzoru:

$$
h_{z}=23 \cdot \sqrt{\sum m+2}
$$

gdzie $\sum m$ - wartość bezwzględna średniej wieloletniej sumy średnich ujemnych wartości temperatury powietrza z miesięcy zimowych.

Autorzy normy z 1955 roku mieli do dyspozycji dane klimatyczne z mniej niż 10 lat, chyba że korzystali także z wcześniejszych, sprzed 1939 roku. Być może korzystali również ze wzoru Dębskiego (Dębski, 1938) i z obliczonych przez niego wartości tzw. miernika temperatury z 27 stacji meteorologicznych, które po 1945 roku znalazły się w nowych granicach Polski. $Z$ pewnością jako miarodajne uznali wartości obliczone na podstawie danych z najbardziej mroźnej zimy z rozpatrywanego przez nich okresu, a może i zimy 1928/1929.

\section{Dotychczasowe propozycje nowej mapy przemarzania gruntu}

Potrzeba opracowania nowej mapy była wyrażana już dawno (Ickiewicz i Pogorzelski, 1987; Kozłowski, 2003), jednak dopiero ostatnio przedstawiono jej dwie propozycje w pracach Gontaszewskiej (2010) oraz Ickiewicz (2010). Obie polegają na zastosowaniu tzw. współczynnika mrozowego, czyli liczby stopniodni ujemnej temperatury powietrza. Gontaszewska obliczyła wartości tego współczynnika na podstawie danych pomiarowych temperatury powietrza z 19 stacji meteorologicznych z lat od 1955/1956 do 1980/1981, a w przypadku kilku stacji także z zim 1920/1921, 1921/1922 i 1936/1937. Dokonała także pewnej modyfikacji wzoru Berggrena-Aldricha, przekształcając go do postaci:

$$
h_{z}=a \cdot \sqrt{0,9 \cdot A F I}
$$

gdzie: $a \quad-$ współczynnik zależny od rodzaju gruntu,

$A F I$ - tzw. wskaźnik mrozowy (ang. air freezing index), czyli liczba stopniodni.

Autorka podała następujące wartości współczynnika $a$, zależne od rodzaju gruntu: piaski grube i średnie $-0,058$, piaski drobne i pylaste $-0,054$, pyły i gliny piaszczyste $-0,048$ oraz iły $i$ inne gliny $-0,040$.

Wartości współczynnika mrozowego $(A F I)$ oraz ich rozkład terytorialny w Polsce, według propozycji Gontaszewskiej (2010), przedstawia rysunek 2. Przyjęła ona wartości AFI z zimy 1962/1963 jako maksymalne spośród wyliczonych. Zapewne na tej podstawie wykreśliła mapę pokazaną na rysunku 2. Nie wykonała żadnych obliczeń probabilistycznych.

Ickiewicz (2010) podała maksymalne wartości wskaźnika mrozowego z ostatnich 80 lat, które wystąpiły podczas zimy 1982/1983 w 13 miastach i na tej podstawie zaliczyła je do proponowanych trzech stref przemarzania gruntu (tab. 1). Autorka nie przedstawiła mapy, lecz napisała, że ,za celowe uważa się wykonanie podziału terenu Polski na strefy klimatyczne w zależności od wskaźnika $F_{d}$ ”. Jako graniczne byłyby wartości następujące: między strefą I a II $F_{d}=1000$, a między strefą II a III $F_{d}=750$. Zatem do strefy I byłby zaliczony obszar o liczbie stopniodni $F_{d}>1000$, do strefy II - o wartościach $750 \leq F_{d} \leq 1000$, a do strefy III $-F_{d}<750$.

Ta propozycja pokrywa się w dużym stopniu z mapą podaną przez Gontaszewską (rys. 2). Granica między strefami I a II (izolinia 1000) przebiegałaby na zachód od Olsztyna, Łodzi, Sandomierza i Przemyśla. Strefa III obejmowałaby obszar nadmorski, a strefa II - zachodnią i południową Polskę z wyłączeniem pewnych enklaw (Kraków, Jelenia Góra), które do tych stref nie należą. Także, według Ickiewicz, wskazane byłoby wyłączenie z tego podziału na strefy terenów górskich, położonych powyżej 1000 m n.p.m. 


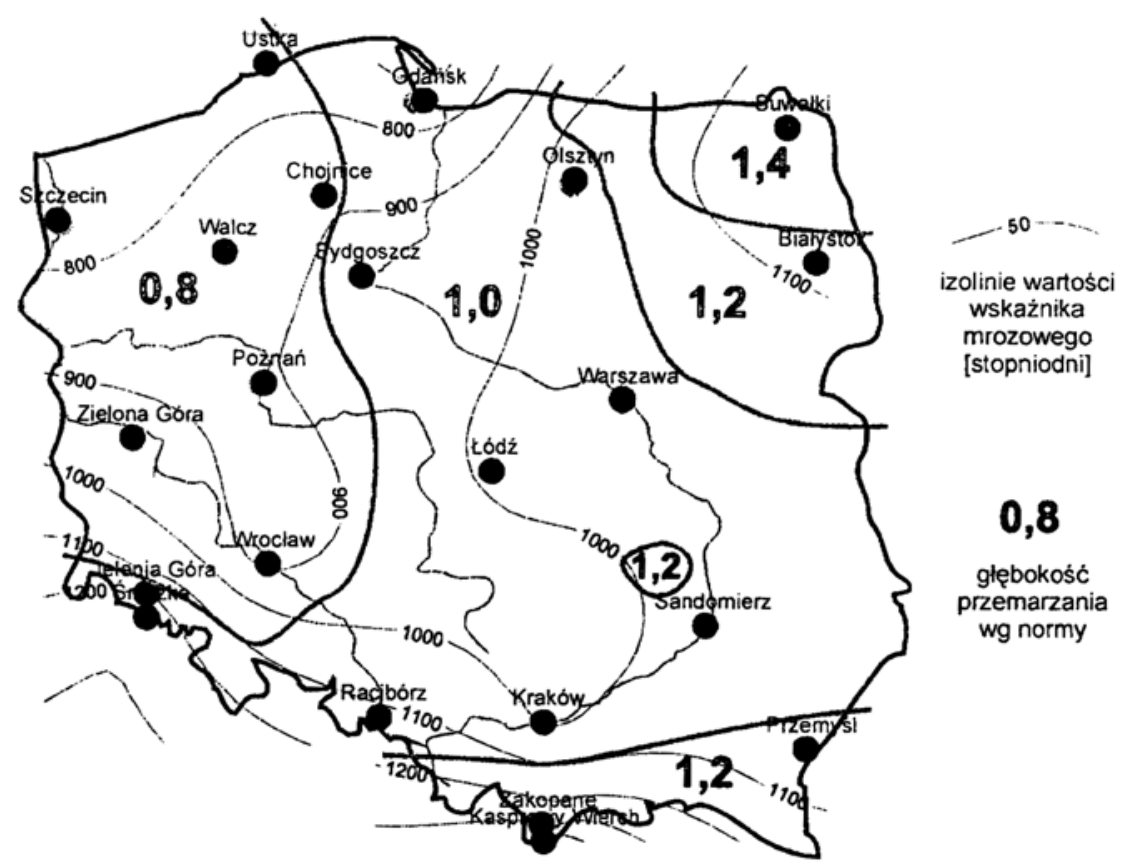

Rys. 2. Mapa maksymalnych wartości wskaźnika mrozowego w stopniodniach - cienkie izolinie (Gontaszewska, 2010) oraz strefy głębokości przemarzania gruntu w metrach - grube izolinie i duże liczby (PN-81/B-03020)

Fig. 2. Map of maximal values of the air freezing index in degreedays - thin isolines (Gontaszewska, 2010) and zones of soil freezing in meters - thick lines and big numbers (PN-81/B-03020)

Tabela 1. Maksymalne wartości stopniodni $\left(F_{d}\right)$ temperatury ujemnej, jakie wystąpiły w zimie 1952/1953 w wybranych 13 miastach Polski oraz proponowane strefy przemarzania (Ickiewicz, 2010)

Table 1. Yearly Maxima values of negative temperature degreedays $\left(F_{d}\right)$, which occurred during the winters 1962/1963 in 13 selected towns of Poland and proposed zones of soil freezing (Ickiewicz, 2010)

\begin{tabular}{|c|c|c|c|c|c|c|c|}
\hline $\begin{array}{l}\text { Miasto } \\
\text { Town }\end{array}$ & Gdańsk & $\begin{array}{c}\text { Suwałki } \\
\text { Jelenia Góra }\end{array}$ & $\begin{array}{c}\text { Olsztyn } \\
\text { Warszawa }\end{array}$ & Szczecin & $\begin{array}{l}\text { Poznań } \\
\text { Chojnice } \\
\text { Wrocław }\end{array}$ & $\begin{array}{c}\text { Łódź } \\
\text { Sandomierz } \\
\text { Przemyśl }\end{array}$ & Kraków \\
\hline $\begin{array}{l}\text { Liczba stopniodni } \\
\text { Degreedays }\end{array}$ & 652 & $\begin{array}{l}1156 \\
1127\end{array}$ & $\begin{array}{l}1060 \\
1019\end{array}$ & 718 & $\begin{array}{l}897 \\
892 \\
850\end{array}$ & $\begin{array}{l}1029 \\
1027 \\
1007\end{array}$ & 973 \\
\hline $\begin{array}{l}\text { Proponowana } \\
\text { strefa } \\
\text { Proposed zone }\end{array}$ & III & I & I & III & II & I & II \\
\hline
\end{tabular}

Autorka napisała: „Granice stref przyjęto dla najmroźniejszej zimy (ze 100-letnim okresem powrotu)”, jednak żadnych obliczeń probabilistycznych nie przedstawiła. Ponieważ rozpatrywała dane dotyczące temperatury powietrza z okresu 1920-2010, a zatem z 90 lat, a w tym przedziale czasu najmroźniejsza była zima 1962/1963, więc zapewne uznała, że dane z tej zimy są miarodajne i można przyjąć, że odpowiadają one okresowi powrotu 100 lat. 


\section{MATERIAL I METODY}

\section{Dane pomiarowe temperatury gruntu}

Przedstawione wyżej propozycje nowych głębokości przemarzania można skonfrontować z wynikami analizy rzeczywistej temperatury gruntu. Na kilkudziesięciu stacjach meteorologicznych Instytutu Meteorologii i Gospodarki Wodnej - Państwowego Instytutu Badawczego są obecnie rutynowo wykonywane ciągłe pomiary automatyczne na głębokościach: $0,05,0,10,0,20$ oraz $0,50 \mathrm{i} 1 \mathrm{~m}$. Wcześniej wykonywane były pomiary jedynie w terminach: 6, 12 i 18 UTC (uniwersalnego czasu koordynowanego, uprzednio nazywanego czasem Greenwich), a na głębokości $1 \mathrm{~m}$ - tylko o godzinie 12 UTC (przy czym w większości przypadków regularnie dopiero od 1982 roku). Wyniki tych pomiarów zostały wykorzystane w prezentowanej pracy.

Technikę pomiarową i metodykę wyznaczania położenia izotermy zerowej $\mathrm{w}$ gruncie podano $\mathrm{w}$ instrukcji Janiszewskiego (1988). Do końca XX wieku pomiary wykonywano za pomocą specjalnych rtęciowych termometrów kolankowych, o skalach do odczytu znajdujących się nad gruntem, a na głębokości $1 \mathrm{~m}$ - za pomocą termometrów wpuszczanych $\mathrm{w}$ rurkę umieszczoną $\mathrm{w}$ gruncie i wyciąganych do odczytu. Poletko pomiarowe o wymiarach $2 \times 4 \mathrm{~m}$ musi być oczyszczone $\mathrm{z}$ trawy i chwastów i nie może być zacienione. Dłuższe boki poletka powinny być zorientowane w kierunku wschód - zachód.

Na podstawie wykonanych pomiarów obserwator na stacji meteorologicznej wyznacza położenie izotermy zerowej (Żurański i Sobolewski, 2013). Zanim zaczęto pomiary na głębokości $1 \mathrm{~m}$, zdarzały się często przypadki, że izoterma zerowa znajdowała się poniżej najgłębszego pomiaru, który był wykonywany na głębokości $0,5 \mathrm{~m}$. W dzienniku obserwacji zapisywano wówczas położenie izotermy zerowej „poniżej $50 \mathrm{~cm}$. Obecnie taka sytuacja zdarza się rzadziej, tylko wtedy, gdy położenie izotermy zerowej znajduje się poniżej $1,0 \mathrm{~m}$. Wówczas, aby uzyskać jej położenie, należy dokonać ekstrapolacji wyników pomiarów z głębokości 1,0 m i mniejszych. Szczegółowe informacje są podane w pracy Żurańskiego i Sobolewskiego (2016).

\section{Metoda opracowania danych pomiarowych}

Prognozowane wartości położenia izotermy zerowej w gruncie oblicza się, aproksymując wybranym rozkładem prawdopodobieństwa rozkłady empiryczne wartości maksymalnych rocznych (zimowych). Podobnie jak w przypadku innych oddziaływań klimatycznych dobrze nadaje się do tego rozkład Gumbela (Gumbel, 1958). Jego dystrybuanta jest przedstawiona wzorem:

$$
F(Z)=\exp \{-\exp [-\alpha(Z-U)]\}
$$

gdzie $\alpha$ i $U$ są parametrami rozkładu.

Funkcja rozkładu Gumbela (3) po jej dwukrotnym zlogarytmowaniu przyjmuje postać równania linii prostej:

$$
Z=U-\frac{1}{\alpha} \ln [-\ln F(Z)]
$$

Właściwość ta pozwala na łatwą konstrukcję tzw. siatki prawdopodobieństwa rozkładu Gumbela, na której można przedstawić dystrybuantę empiryczną i porównać z równaniem prostej. Przykłady zastosowania podano na rysunkach 3 i 4 . Prosta teoretyczna została dopasowana do rozkładu empirycznego metodą najmniejszych kwadratów. 


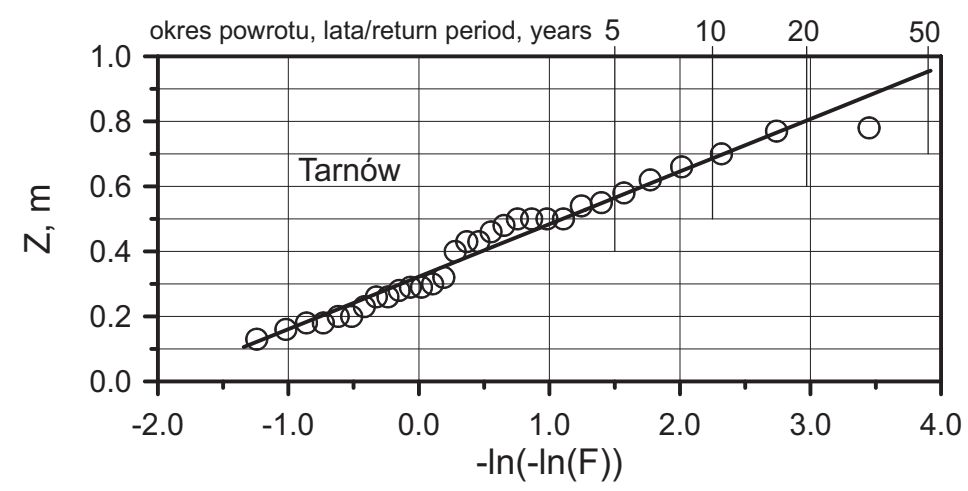

Rys. 3. Rozkład wartości maksymalnych rocznych głębokości położenia izotermy zerowej na siatce probabilistycznej Gumbela, stacja meteorologiczna w Tarnowie

Fig. 3. Maxima of the zero centigrade temperature depth presented on the Gumbel probability plot, meteorological station in Tarnów

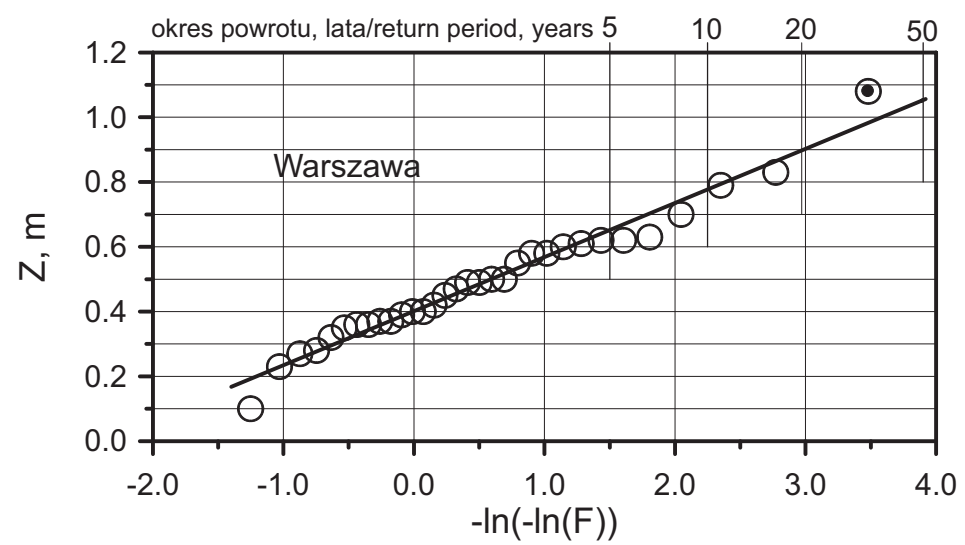

Rys. 4. Rozkład wartości maksymalnych rocznych głębokości położenia izotermy zerowej na siatce probabilistycznej Gumbela, czarnym punktem oznaczono wartość uzyskaną z ekstrapolacji, Warszawa-Bielany

Fig. 4. Maxima of the zero centigrade temperature depth presented on the Gumbel probability plot, black point indicates extrapolated value, Warszawa-Bielany

\section{WYNIKI}

Stosując podany wyżej rozkład Gumbela, oszacowano jego parametry i wykonano obliczenia wartości prognozowanych położenia izotermy zerowej w gruncie. Przyjęto, że tak jak w przypadku oddziaływań klimatycznych wartości charakterystyczne położenia izotermy zerowej powinny mieć okres powrotu 50 lat. Otrzymano położenie izotermy zerowej w warunkach gruntowych 45 stacji meteorologicznych, na których były wykonywane pomiary. Na głębokość przemarzania ma wpływ rodzaju gruntu, jego stan, stopień nasycenia, porowatość i skład mineralny oraz układ warstw. Przystępując do przeliczenia otrzymanych wyników na jednolite warunki gruntowe, należy ustalić warunki w podłożu analizowanych stacji meteorologicznych - ustalić profil, w którym były wykonywane pomiary temperatury. W tym celu należy dokonać normalizacji i ustalić tzw. grunt odniesienia (referencyjny), do którego zostaną odniesione wyniki obliczeń. W przypadku 31 stacji meteorologicznych warunki gruntowe ustalono na podstawie informacji zawartych w opisach profili glebowych stacji IMGW-PIB. Pozostałe 
14 stacji nie miały takich opisów; w tych stacjach warunki gruntowe ustalono na podstawie wydzieleń opisanych według Szczegółowej mapy geologicznej Polski w skali $1: 50000$.

Na podstawie tych opisów podzielono grunty na cztery rodzaje, korzystając z pracy Gontaszewskiej (2010). Podział ten jest zgodny z klasyfikacją gruntów według NiTU. Przyjmując głębokość położenia izotermy zerowej w piaskach grubych i średnich (także w żwirze) jako podstawową, można dla innych rodzajów gruntu wprowadzić współczynniki wynikające ze stosunku podanych wartości do wartości maksymalnej $(0,058)$. Przy takim podejściu nowa propozycja mapy przemarzania została opracowana jak dla podłoża/gruntu referencyjnego, w tym przypadku żwirów, piasków grubych i średnich.

Przeliczenie w zależności od rodzaju gruntu jest możliwe przy użyciu następujących współczynników:

- żwiry, piaski grube i średnie: 1,00 ,

- piaski drobne i pylaste: $0,054 / 0,058=0,93 \cong 0,90$,

- pyły i gliny piaszczyste: $0,048 / 0,058=0,83 \cong 0,80$,

- iły $\mathrm{i}$ inne gliny: $0,040 / 0,058=0,69 \cong 0,70$.

Ze względu na przybliżony sposób ustalania rodzajów gruntu zaproponowano zaokrąglone wartości współczynnika. W powyższych rozważaniach nie uwzględniono ponadto tego, że często grunt na stacjach meteorologicznych składa się z kilku różnych warstw, co utrudnia jego klasyfikację. Można przyjąć, z braku innych danych, że te wartości oddają stosunki położenia izotermy zerowej między wymienionymi rodzajami gruntu.

Uzyskane wyniki analizy probabilistycznej danych pomiarowych skorygowano według wartości współczynnika poprawkowego z uwagi na rodzaj gruntu, odnosząc je do jednolitych warunków gruntowych, za które przyjęto żwiry, piaski grube i średnie. Przykładowe wyniki obliczeń podano w tabeli 2, a na podstawie wszystkich

Tabela 2. Przykłady wyników obliczeń znormalizowanych ze względu na rodzaj gruntu

Table 2. Examples of calculation results standardized for soil type

\begin{tabular}{|c|c|c|c|c|}
\hline \multirow{2}{*}{$\begin{array}{l}\text { Stacja } \\
\text { Station }\end{array}$} & \multirow{2}{*}{$\begin{array}{l}\text { Rodzaj gruntu } \\
\text { Soil type }\end{array}$} & \multirow{2}{*}{$\begin{array}{l}\text { Współczynnik } \\
\text { przeliczeniowy } \\
\text { Coefficient of } \\
\text { standardization }\end{array}$} & \multirow{2}{*}{$\begin{array}{c}\begin{array}{c}\text { Wyniki bez korekty } \\
\text { Results without correction }\end{array} \\
\mathrm{Z}_{50}[\mathrm{~m}] \\
\text { MNW }\end{array}$} & \multirow{2}{*}{$\begin{array}{c}\text { Wyniki skorygowane } \\
\text { Standardized results } \\
\mathrm{Z}_{50 \text { kor }}[\mathrm{m}] \\
\text { MNW }\end{array}$} \\
\hline & & & & \\
\hline Białystok & $\operatorname{Pd~i~} \mathrm{P} \pi$ & 0,9 & 1,072 & 1,19 \\
\hline Elbląg & П i Gp & 0,8 & 0,993 & 1,24 \\
\hline Jelenia Góra & $\dot{Z}$, Pr i Ps & 1,0 & 0,986 & 0,99 \\
\hline Kalisz & П i Gp & 0,8 & 1,124 & 1,41 \\
\hline Koło & I i G & 0,7 & 1,006 & 1,44 \\
\hline Kraków Balice & $\operatorname{Pd~i~} \mathrm{P} \pi$ & 0,9 & 0,839 & 0,93 \\
\hline Lublin & П i Gp & 0,8 & 0,960 & 1,20 \\
\hline Łódź & $\mathrm{Pd}$ i P $\pi$ & 0,9 & 1,181 & 1,31 \\
\hline Piła & $\dot{Z}$, Pr i Ps & 1,0 & 1,288 & 1,29 \\
\hline Poznań & П i Gp & 0,8 & 1,308 & 1,64 \\
\hline Rzeszów & $\dot{Z}, \operatorname{Pr}$ i Ps & 1,0 & 0,863 & 0,86 \\
\hline Suwałki & П i Gp & 0,8 & 1,056 & 1,32 \\
\hline Szczecin & $\dot{Z}$, Pr i Ps & 1,0 & 1,124 & 1,12 \\
\hline Warszawa & $\operatorname{Pd}$ i $\mathrm{P} \pi$ & 0,9 & 1,044 & 1,16 \\
\hline Włodawa & $\mathrm{Pd}$ i P $\pi$ & 0,9 & 1,387 & 1,54 \\
\hline Zielona Góra & $\dot{Z}$, Pr i Ps & 1,0 & 1,503 & 1,50 \\
\hline
\end{tabular}


wyników wykreślono mapę (rys. 5). Mapę izolinii opracowano na podstawie danych uzyskanych z szacowania parametrów rozkładu prawdopodobieństwa metodą największej wiarygodności (MNW), izolinie poprowadzono metodą krigingu.

Wyniki analizy wskazują na możliwość utworzenia czterech stref przemarzania, trzech o wartościach takich samych jak w dotychczasowej normie: 1,0, 1,2 i 1,4 m, oraz strefy górskiej o wartości zależnej od wysokości nad poziomem morza, lecz nie mniejszej niż 1,0 m. Całkowicie inny jest podział kraju na strefy. Wstępną mapę stref przedstawiono na rysunku 5, a wartości strefowe w tabeli 3.

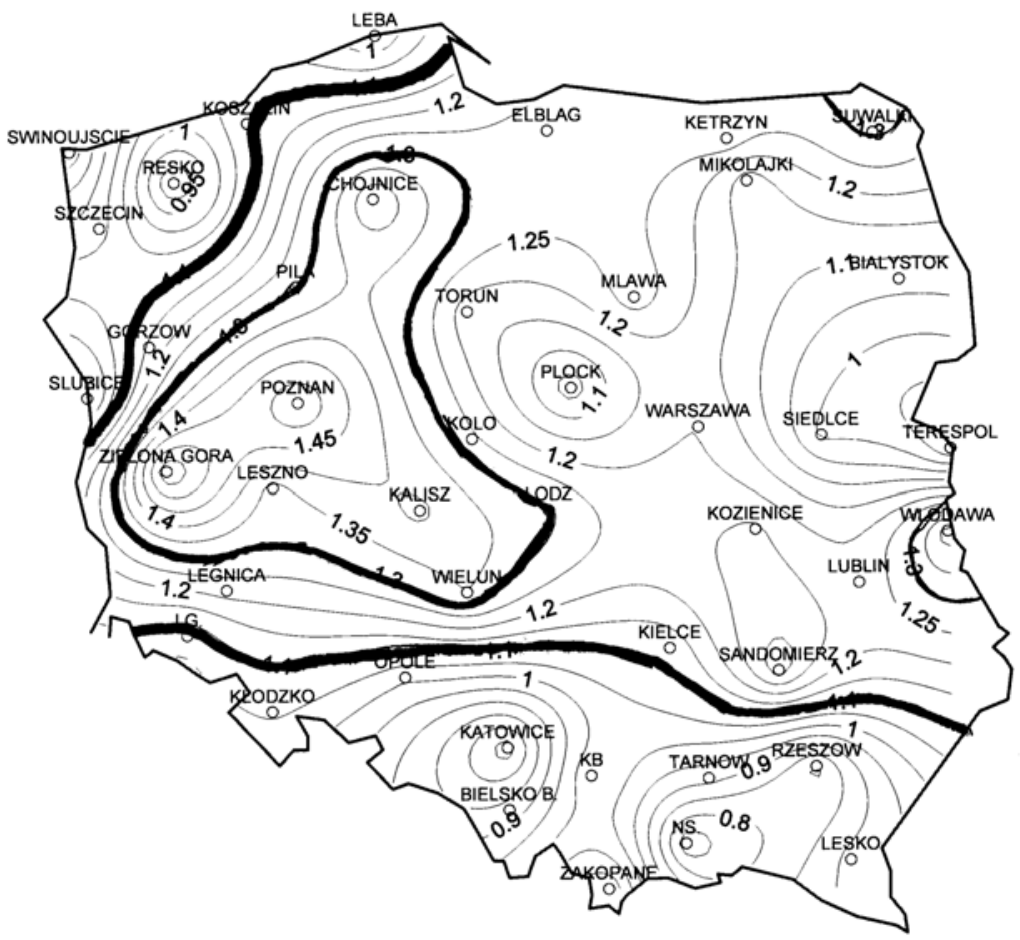

Rys. 5. Wstępna propozycja nowej mapy przemarzania gruntu w Polsce

Fig. 5. Preliminary map of soil freezing depth in Poland

Tabela 3. Wstępne wartości strefowe głębokości położenia izotermy zerowej w Polsce

Table 3. Preliminary zonal values of soil freezing depth in Poland

\begin{tabular}{cc}
\hline Strefa - Zone & $Z_{k}[\mathrm{~m}]$ \\
\hline 1 & 1,0 \\
2 & 1,2 \\
3 & 1,4 \\
4 & $0,6+0,0007 \cdot A ; z_{k} \geq 1,0 \mathrm{~m}$ \\
\hline
\end{tabular}

Proponowana strefa 1., o wartości strefowej $Z_{k}=1,0 \mathrm{~m}$, byłaby położona na terenach bliskich wybrzeża Morza Bałtyckiego. Strefa 2. obejmowałaby większość terytorium Polski, z wyłączeniam trójkąta Wieluń - Zielona Góra - Chojnice - Wieluń, wewnątrz którego byłaby wartość 1,4 m. Na południu Polski byłaby strefa podgórska i górska o wartości zależnej od wysokości nad poziomem morza, lecz nie mniejszej niż 1,0 m. Jej granica północna przebiegałaby, w przybliżeniu, od Przemyśla do Opola i Jeleniej Góry. 
Możliwe jest ograniczenie liczby stref do trzech. Strefa nadmorska oraz podgórska i górska mają tę samą wartość minimalną 1,0 m, a zwiększona głębokość występuje dopiero powyżej wyskości $570 \mathrm{~m}$ n.p.m. Należałoby także wydzielić obszar wokół Włodawy oraz Suwałk, o większej głębokości przemarzania niż w strefie 2.

\section{PODSUMOWANIE}

Uzyskane wyniki świadczą o tym, że należy zmienić dotychczasową mapę, która była opracowana na podstawie obliczeń za pomocą przybliżonych wzorów uwzględniających jedynie temperaturę powietrza. Probabilistyczna analiza temperatury gruntu uwzględnia losowy charakter zjawiska i udział $\mathrm{w}$ nim nie tylko temperatury powietrza, lecz także pokrywy śnieżnej, jak również zawartości wody w gruncie wynikającej z wcześniejszych opadów deszczu, przed wystąpieniem mrozu. Ocena głębokości przemarzania gruntu na podstawie wskaźnika mrozowego ma charakter pośredni, analiza temperatury gruntu uwzględnia koincydencję zjawisk wpływających na głębokość przemarzania. Otrzymane wyniki różnią się od wyników uzyskanych z analizy stopniodni i są bardziej wiarygodne.

Opisany grunt referencyjny bierze pod uwagę jedynie jego rodzaj (litologię). Na obecnym etapie nie było możliwe (brak takich danych) uwzględnienie dodatkowych czynników, które mają wpływ na głębokość przemarzania, jak: stan gruntu, stopień nasycenia, porowatość i skład granulometryczny. Kolejne czynniki, które lokalnie moga mieć istotny wpływ na rzeczywistą głębokość przemarzania, to aktualne położenie zwierciadła wód gruntowych i jej chemizm, sytuacja morfologiczna - możliwość lokalnych anomalii, np. w kotlinach czy na wzniesieniach, oraz uwarunkowania związane z ekspozycją terenu - stoki południowe, obecność i rodzaj szaty roślinnej czy rodzaj zagospodarowania. Proponowaną klasyfikację gruntów, jak również sposób jej uwzględnienia w obliczeniach głębokości przemarzania należy uznać jako podejście wstępne. Wskazane byłoby prowadzenie badań doświadczalnych, których celem, bardzo ważnym, byłoby uściślenie zależności położenia izotermy zerowej od rodzaju gruntu i między położeniem izotermy zerowej a rzeczywistą głębokością przemarzania. Ważne, lecz trudne do uwzględnienia jest uwarstwienie gruntu na stacjach meteorologicznych, czyli sytuacja, gdy grunt na stacji składa się z różnych warstw, różnie reagujących na temperaturę ujemną. Wykonane analizy obejmowały dane pochodzące z pomiarów w warunkach terenowych i klimatycznych, które można nazwać naturalnymi, bez ingerencji w stan gruntu i pokrywę śnieżną. Badania porównawcze mogłyby obejmować grunt $\mathrm{z}$ usuniętą pokrywą śnieżną, a także grunt przykryty różnego rodzaju tworzywem (np. asfalt, bruk, płyty żelbetowe).

Prezentowana praca otwiera nowy rozdział oceny głębokości przemarzania, dotyczący wykorzystania wyników pomiarów temperatury gruntu do prognozowania głębokości jego przemarzania.

\section{ADNOTACJA}

W referacie wykorzystano wyniki pracy wykonanej w ramach tematu statutowego Instytutu Techniki Budowlanej NZK-37 Wybrane oddziaływania klimatyczne na obiekty budowlane, finansowanego przez Ministerstwo Nauki i Szkolnictwa Wyższego.

\section{PIŚMIENNICTWO}

Dębski, K. (1938). Wstępne badania funkcji zamarzania gruntów w Polsce. Wiadomości Stużby Hydrograficznej, 5, 57-69. Gontaszewska, A. (2010). Własności termofizyczne gruntów w aspekcie przemarzania. Zielona Góra: Uniwersytet Zielonogórski.

Gumbel, E. J. (1958). Statistics of extremes. New York: Columbia University Press.

Ickiewicz, I. (2010). Posadowienie fundamentów bezpośrednich w funkcji przemarzania gruntów. Rozprawy Naukowe, 202. Biblioteka Budownictwa. Białystok: Oficyna Wydawnicza Politechniki Białostockiej. 
Ickiewicz, I. i Pogorzelski, J. A. (1987). Wpływ wybranych czynników na głębokość przemarzania gruntów. Inżynieria i Budownictwo, 1/12, 338-342.

Janiszewski, F. (1988). Instrukcja dla stacji meteorologicznych. Instytut Meteorologii i Gospodarki Wodnej. Warszawa: Wydawnictwa Geologiczne.

Kozłowski, T. (2003). Głębokość przemarzania krajowych gruntów budowlanych w aspekcie PN-81/B-03020 i projektu jej zmian. Inżynieria i Budownictwo, 3, 168-170.

NiTU - 127-50. Normatiwnyje i Tiechniczeskije Ukazania.

PN-81/B-03020. Grunty budowlane. Posadowienia bezpośrednie budowli. Obliczenia statyczne i projektowanie.

Wiłun, Z., Piastowski, A. i Kowalewski, Z. (1962). Przemarzanie gruntów. Informator Instytutu Technicznego Wojsk Lotniczych, Seria A, 5, Warszawa.

Żurański, J.A. i Sobolewski, A. (2013). O pomiarach temperatury gruntu i prognozowaniu głębokości jego przemarzania. Inżynieria i Budownictwo, 3, 141-145.

Żurański, J. A. i Sobolewski A. (2016). Probabilistic Approach to the Assessment of the Depth of Soil Freezing. 13th Baltic Sea Region Geotechnical Conference, Vilnius, Lithuania, 21-24 September, Proceedings, J. Medzvieckas (ed.). Vilnius Gediminas Technical University (VGTU) Press.

\section{ABOUT WORKS ON A NEW MAP OF SOIL FREEZING DEPTH IN POLAND}

\section{ABSTRACT}

In the paper present state of the codification of soil freezing depths in Poland and their map is presented as well as last proposals of their changes. Two of them are based on the use of so called air freezing index that is a method of "degreedays" based on calculation of the number of days with minus air temperature. New approach presented in the paper is based on the results of measurements of soil temperature carried out by meteorological stations belonging to the Institute for Meteorology and Water Management - State Research Institute. Annual (winter) maxima of the position of the zero centigrade temperature measured in the soil were approximated by Gumbel probability distribution of extremes and characteristic values of 50 year return period have been calculated. The soil conditions at the meteorological stations were taken into consideration and correction coefficients have been proposed. Proposal of a new map of soil freezing depth in Poland is presented for the soil assumed as a reference one.

Key words: soil temperature, probability distribution, return period, depth of the zero centigrade isotherm 